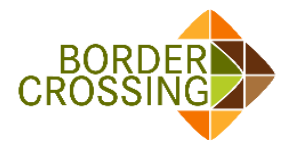

Submitted: 16 August 2018; Accepted: 1 November 2018

\title{
Turkish Teachers and Schools in the Eyes of Refugee Students
}

\author{
Aysun Dogutas ${ }^{ \pm}$
}

\begin{abstract}
This study aimed to reveal how refugee students think about their Turkish teachers and schools through art. This study was done using an art based research method, proposed as a way of analysis by Mullen (2003) and Huss and Cwikel (2005). The study was carried out with 25 refugee students from two primary schools in the central city of Denizli in the 2017-2018 academic years. During the study, the students were asked to draw a picture of a teacher on one side of a paper and draw a picture of a school on another side of the paper. Later, students, who can speak Turkish, were asked to say a phrase about the school and teacher concepts. Phrases and drawings of the refugee children about the image of their teacher and school show us that these students have positive opinions about their teachers and schools.
\end{abstract}

Keywords: Art based research; refugee students; teacher; school.

\section{Introduction}

Turkish schools are very crowded and enroll many students from different environments, cultures and countries. Teachers deal with these differences while trying to teach their subjects. It is not easy to teach students from different backgrounds, cultures and environments; besides this, the number of refugees complicates the classroom culture. The Turkish government welcomes refugee students to schools; however, teachers' and refugee students' attitudes is also important to have a safe environment for both Turkish and refugee students in the classroom. Can refugee students adapt to school, class, and friends and especially to their teachers? What do these students think about their teachers?

A teacher is the one who creates the psychological environment of the classroom by her personality traits. Important traits include: getting on well with her surrounding, making friends easily, being tolerant, being aggressive or calm, and being tough or easy with the students (Arslan Cansever, 2017). Since students see the teacher as a role model for themselves, teachers' behaviors are important. An educational environment is influenced by the personality and behavior of a teacher (Aslan, Aslan and Arslan-Cansever, 2012).

The responsibility of carrying out effective educational activities is relegated to teachers. Teachers are responsible for organizing activities, arranging learning environment and so on. Thus, teachers are guiding students in every aspect. If students like their teachers they can adapt to school easily because

^Dr Aysun Dogutas, Pamukkale University, Denizli, Turkey. Email: adogutas@pau.edu.tr. 
teachers are very important in education environment. When considered from this point of view, it is important to determine how teachers are perceived by students, since teachers play significant roles in the classroom and influence the lives of students in general (Aykac, 2012).

\section{Refugee Children in Turkish Schools}

The rates of refugees and asylums are increasing day by day in Turkey. Parallel to global dynamics, the number of irregular refugees increasing in Turkey. As the date of 31 January 2013, the total number of refugees is 19,203 and asylum seekers are 13,703 except Syrians. Then it reached 21,956 of refugees and 14,758 of asylum seekers in June of the same year (Kartal and Basci, 2014 in Dogutas, 2018). Within determined illegal migration, children's rate is $17 \%$ of adults. This number shows that children are an importantly large group in irregular migration (Atasu Topcuoglu, 2012). Thus, there are many refugee children in Turkish schools. The Turkish government created laws to protect refugee children's rights. In 2010 circular, MEB accepted that there are some troubles with the education of refugee and asylum seeker children. They stated that "according to the sensations and requests reverted to the Ministry, it can be understood that some troubles and hesitations on foreign nationals' utilization of education and training are being lived" (MEB Genelge, 2010). Since only $64 \%$ of refugee and asylum seeker children can go to school (Kartal and Basci, 2014).However, just including them to the Turkish school environment and curriculum may not solve all concerns of refugee children. Can they adapt to school, friends and especially to teachers, who are the most important people for students, as stated above?

Some of these refugee children come with traumatic previous experiences. Refugee children cannot simply forget what has happened, despite trying very hard to do so. If they were able to forget, they would deny their history and experience, often the existence of other family members who have been lost (Dogutas, 2018). Even if they cannot forget what they experienced, they can adapt to new environment. Thus, if the school environment provides positive features, refugee children's adaptation to school as well as their sense of belonging and academic success increases. By contrast, a negative environment causes alienation and divergence from school (Dogutas, 2018). Since most of the responsibility is on teachers, teachers' reactions, expressions, and behaviors affect children's individual, social, and cognitive development (Dogutas, 2018).

Some of these refugee children cannot speak or write Turkish. However, it is important to see what these children think about school, friends and especially about their teachers since teachers have the vital role in an effective education. They cannot express themselves easily in writing since they don't 
know the Turkish language. Therefore this study benefits from using drawings from the children.

\section{Art and Children}

Children's drawings are considered to be a mirror of the narrative/symbolic development of the child. For young children, drawing is the language of thought expression (Cherney, Seiwert, Dickey, and Flichtbeil, 2006). Art has a significant place in children's cognitive development. Within art types, drawing has an important place for identity, proving, perceiving and portraying creatures within nature. Drawing and child is a complementary phenomenon. Drawing is an important and affective way of communication with children (Artut, 2007). Drawing is a more powerful narrative, reflective and expressive instrument than a statement that children may express by words, and is accepted as an indicator of children's perceptions of the outside world (Can Yasar and Aral, 2009). In drawings, children can express things too huge or too small as to their thinking; they can use shapes, colors and metaphors in their drawings. Since some of refugee children can't speak Turkish and some others cannot express themselves well by wording, drawing will help us to understand their feelings and thoughts.

\section{Art as a Way of Telling}

Visual culture, a synthesis based on seeing things and on what is shown (Karadag, 2004, p. 13), is the determiner of the responses given to television, movies, advertisements, art works, constructions and urban environments (McRobbie, 1999; Mirzoeff, 1998; Mitchell, 1995; Rogoff, 1998). According to the codes and images of culture which has been shaped by individuals starting from birth, people start forming new meanings from their own perspectives (Türkkan, 2008). Especially when children's drawings are considered to be a language, children will use them to express themselves sincerely (Turkcan, 2013). As mentioned by Yavuzer (2009), drawing could be regarded as an indicator of mental development and as a way of expressing his or her complex inner world that a child tries to organize on his or her own.

Children represent their relationship with teachers in their drawings naturally. Having children draw pictures is the most appropriate method to get children's feelings in depth. Children reflect their feelings, thoughts, and manners in drawings (Harrison, Clarke and Ungerer, 2007; Fury, Carlson and Sroufe, 1997). Studies on children's drawings about their feelings and thoughts are used as a way of diagnosis in psychology.

A child has a chance to express feelings and thoughts in detail by drawing pictures. Scholars believe it is possible to determine how children perceive their environment and human relations through drawings (Aykac, 2012). In many studies, researchers tried to determine the quality of children's 
interpersonal relationships by drawing themselves, their parents and environments (Clarke, Ungerer, Chahoud, Johnson and Steifel, 2002; Fury et al., 1997; Kaplan and Main, 1985; Pianta, Longmaid and Ferguson, 1999). Studies done on children's drawings are very important since they reflect children's feelings and thoughts naturally and without effort. Children can express themselves freely in drawings. Since 1800s, many researchers have been using drawings as a data collection method (Barnes, 1893; Harrison, Clarke and Ungerer, 2007; Selwyn, Boraschi and Ozkula, 2009; Barman, 1997). Drawing as a narration, expression and reflection is more powerful than children's statements with words. Thus, drawing is accepted as an indicator of perception of children's outside world (Yasar and Aral, 2009).

\section{Previous Studies in Turkey}

In recent years, studies done on drawing analysis have increased. In Turkey, studies on drawing analysis are mostly about the image of a "scientist" (Gültekin, Tosun, Turgut, Örenler, Şengül, and Top, 2010; Oguz-Ünver, 2010). Additionally, there are many studies which explore the perception of the teacher such as Ahi, Cingi, and Kıldan, 2016; Aykac, 2012; Çam Aktaş, 2010; Harrison, Clarke, and Ungerer, 2007.

One such study about perceptions of teachers was conducted by Aykac (2012). The aim of the study was to reveal how elementary and secondary school students perceive their teacher and teaching process as reflected in their drawings. In this study, 1000 students from 3rd, 4th, 5th, 6th, 7th and 8th grades of the schools located in Hakkari, Van, Ankara and Muğla cities participated. According to the findings, the students mostly depicted their teachers as "human" and just a small number of students illustrated them as a well-known person such as "Atatürk" or sun, flower, heart, book, etc. When the students' drawings were evaluated in terms of teaching process, it was observed that teachers are mostly illustrated inside the class, at the board, and standing next to the board or teaching with chalk in their hand.

Another similar study was done by Sadık, Cakan and Artut (2011). This study aimed at investigating the perceptions of 11-12 year-old children on environmental problems by means of their pictures. In total, 206 children from three primary schools, located in neighborhoods of different socioeconomic levels, participated in the study. According to the analysis, it was found that the children focused on more than one environmental issue in their pictures and illustrated the issues in cause and effect relationships. The results also showed that violent behavior, pollution and deforestation were environmental issues perceived as the most common by children from low socio-economic levels. In contrast, air-pollution and species extinction were perceived by the high socio-economic children. Akbulut and Saban (2012) aimed to investigate primary school students' perceptions of violence by means of their drawings. 
Thus, similar to previous studies, current study aimed to get refugee students' opinions and thinking about teacher and school image in their minds through art. It is important to get refugee students' ideas about teacher and school in their new environment since it is not easy to adapt and accept new conditions. Hence the research questions of the current study are: Can these students adapt to school, class, and friends or especially to their teachers? What these students think about their teachers? Do they love or hate their teachers?

\section{METHOD}

This study presents an art based research method which includes the usage of art as a method, a way of analysis and as an object (Mullen, 2003, Huss and Cwikel, 2005). The art-based research model is one of qualitative research methods (Huss and Cwikel, 2005). Forms of expression in different fields of art are analyzed systematically in art based research (Mcniff, 1998, p. 29). Art based research is used for evaluating, interpreting, and exploring educational conditions within the qualitative research realm. In art based research, one approach uses drawing by children (Dotson, 2007). For a long time drawings appeared in psychology and psychotherapy fields, and in recent years they have been used to understand children's knowledge, experiences and worldviews (Leitch, 2008).

\section{Art Based Research}

In 1975, Elliot Eisner, who has been one of the most important supporters of the application of art inside research processes, introduced the term artsbased education research (ABR) (Pentassuglia, 2017). “Greenwood (2012) argued that practices based on the $A B R$ approach respond to the need to both bring out and share understandings and phenomena that are difficult to read properly through traditional approaches" (Pentassuglia, 2017; 3) . In recent years, $A B R$ has been recognized as a legitimate and useful methodological approach especially in education field (Greenwood, 2012).

$A B R$ can be defined as an effort to go beyond restrictions that limit communication in order to express meanings that otherwise could be unintelligible (Barone and Eisner, 2012). The acquisition of multiple meanings; this means to reach a wider and more complete vision of reality that not only opens up to new questions and ways of knowing, but further allows a new kind of communication with stakeholders and all actors involved in the research process.

\section{Study Group}

The criterion sampling method, one of purposeful sampling methods was used to determine the participants of the study (Yıldırım and Şimşek, 2005). 
The criterion for the sampling was determined by the researcher according to the students' being a refugee in Turkish schools, willingness to volunteer, and living in the central city of Denizli during the 2017-2018 academic years. In addition, the primary school was used rather than the secondary school based on the assumption that primary school students will use their drawings more comfortably than older students. A total of twenty-five students, fourteen of whom were boys and eleven were girls. Ten of refugee students were illiterate and fifteen of them were literate. The ages of the participant were diverse and as follows; age eight, three students; age nine, seven students; age ten, six students; age eleven, five students; age twelve, three students and age thirteen, one student.

\section{Data Collection Process}

Before the data could be gathered, the necessary permissions were received from the Provincial Directorate for National Education of Denizli. After receiving National permission, the school administrators were informed of the study and they then provided permission. With the help of the school leadership, the study was explained to the school counselors so they could assist the researchers in conducting the study. The data were gathered in the office of school counselors. To protect research validity and reliability, the data (drawings) were not collected in the classrooms. Instead, the children were invited to the counselors' offices. Akbulut and Saban (2012) recommended that the data should be gathered outside the classroom or in classroom while teachers were out for the sake of validity and reliability.

The school counselors were used as a proxy for the researcher because the researcher would have been a stranger to the participants. Refugee students knew the school counselor and could relax with them while drawing. They might not be comfortable with a stranger.

Each participating student was asked by the counselor to draw a picture of a teacher on one side of a paper and to draw a picture of a school on the other side of the paper. Students, who knew how to write in Turkish, were asked to write a phrase about their understanding of teachers and schools.

During the development of this study experts in qualitative research were consulted." This consultation included their views on planning, application and ending phases of the study. Field experts were three academicians from the art department of a university. These field experts were chosen since they had studies on students' drawings and art based research.

\section{Data Analysis}

Students' writings, field experts' comments and the researcher's interpretations were analyzed for this study. That data included students' figures, lines and colors in their drawings, and what they tried to tell in their 
drawings. Each of these components were described and interpreted. Next, the common components found in each drawing were revealed and analyzed. Each field expert and the researcher analyzed the pictures separately. Later, they all got together and compared the themes. At the last stage, three field experts and the researcher found common themes and categories.

In the findings section, students' pictures are described and examples of the emergent themes will be presented. In quotations and examples from the pictures and students' opinions, code names were used for students. In order to protect their identity, at the beginning of the analyses, a code name was given to each student and also the two schools.

\section{FINDINGS}

Findings will be presented in two sections. The first section will be the image of teacher. The second section will include the image of school. This organization reflects the order of the data collection. The students drew a picture of a teacher on one side of a paper and then they drew a picture of a school on the other side. Student who could write in Turkish wrote their descriptions near their pictures. For instance, a child would write a phrase about a teacher under their drawing for a teacher. In the cases where the student could not write in Turkish, the counselor wrote the student comments for them.

When we review what students think about a teacher, eight students said that a teacher means teaching and learning (See picture 1). Six students said a teacher means love (See picture 2).

\section{Picture 1:}

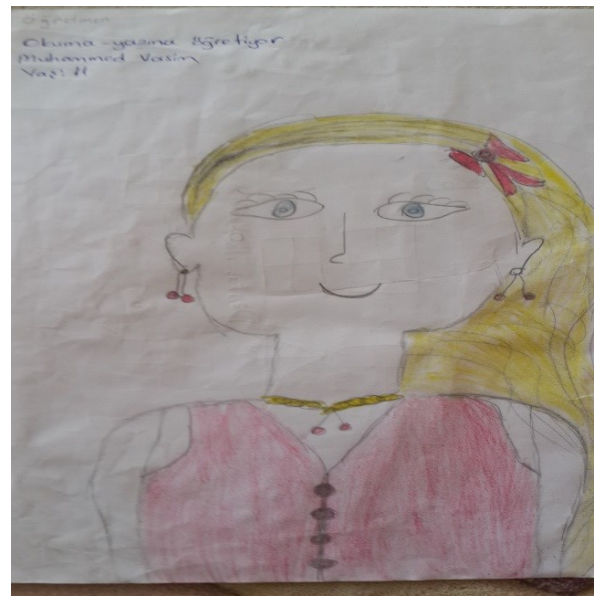

\section{Picture 2:}

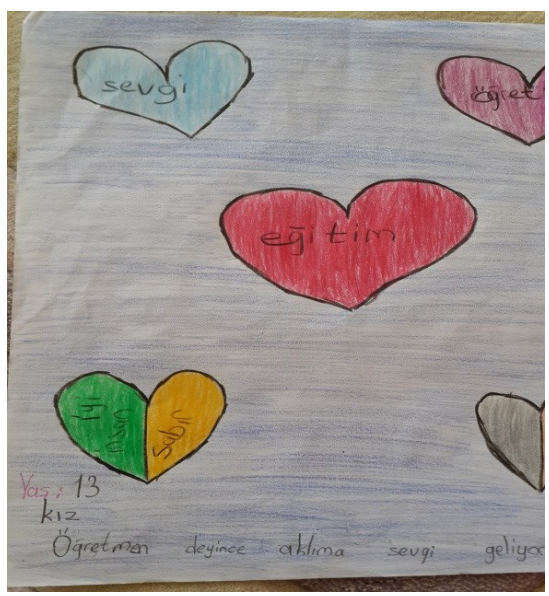

While most of the students said that a teacher means teaching, learning and love, one of the students said that a teacher means mother (See picture 3). 


\section{Picture 3:}

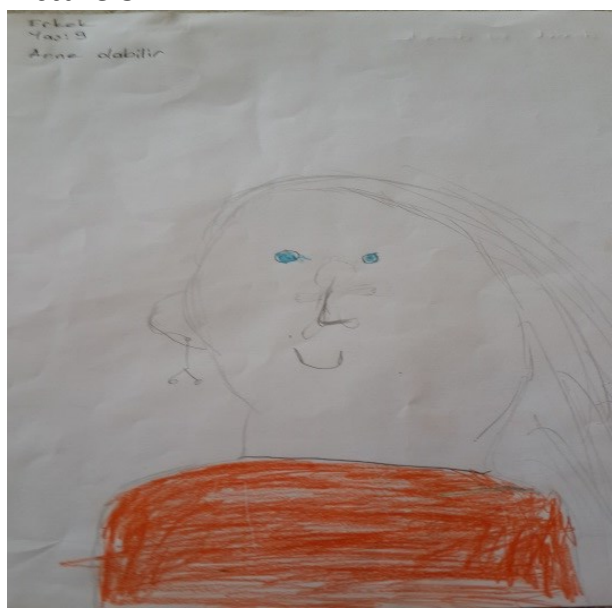

On the other hand, when we look at the drawings of the students, there are some outstanding images. For example, eleven students drew a heart in their pictures. Some of them draw hearts next to the teacher (See picture 4) and some of them drew a teacher inside a heart (see Picture 5)

\section{Picture 4:}

Picture 5:

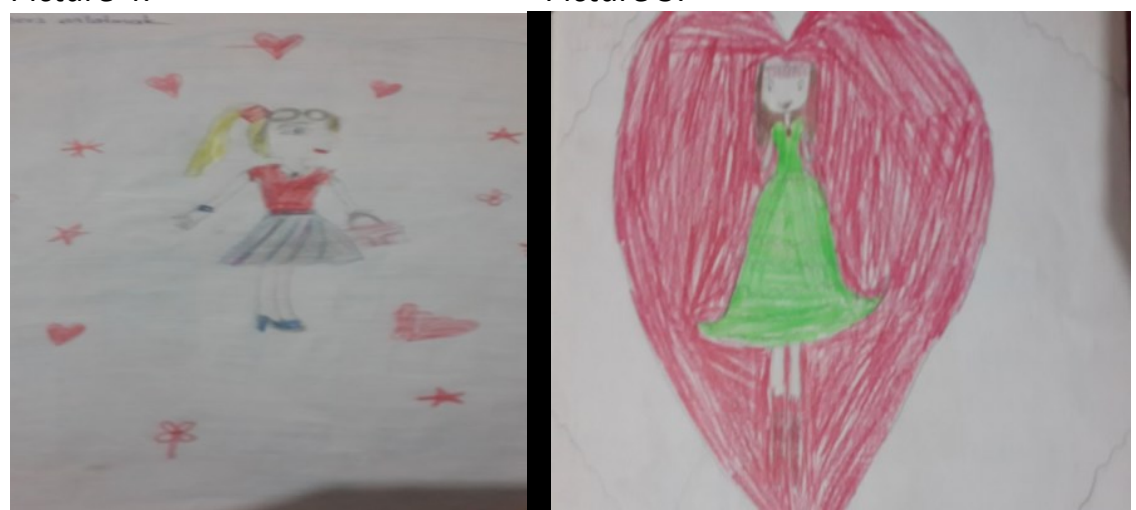

Some drew many hearts and some drew a big heart. Another image which was outstanding was a flower. Seven students drew flowers in their picture of a teacher. They had many flowers included in the picture (see picture 6). One of the students just drew a picture of a flower and said a teacher is a flower (see picture 7). 
Picture 6:

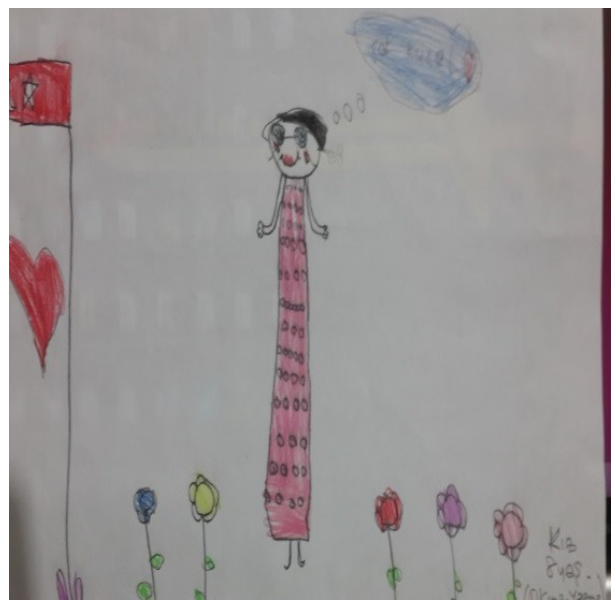

Picture 7

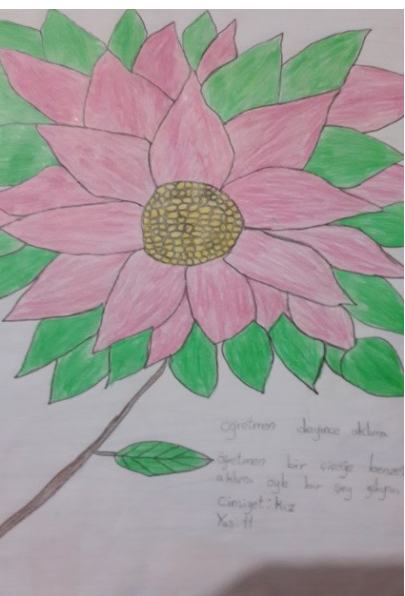

When we review what students think about school, there are two outstanding opinions. One of the students said that "when I think about school traffic rules come into my mind" (See picture 8). Another student said that "when I think about school I think about home" (See picture 9).

\section{Picture 8}

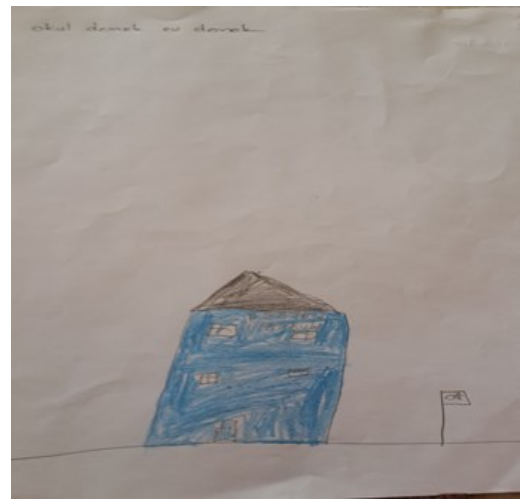

Picture 9

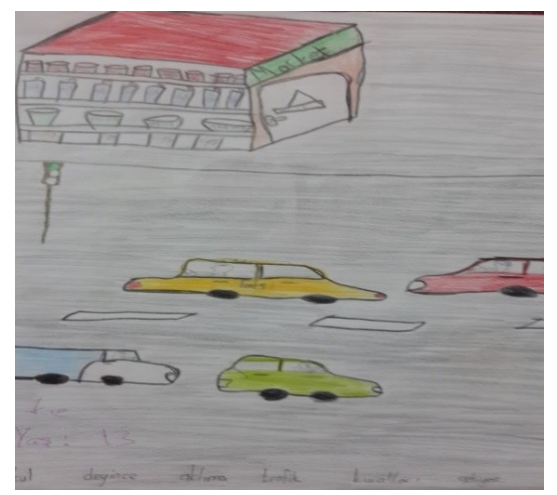

Many students said that they see school as a place of reading-writing and teaching (see picture 10). 


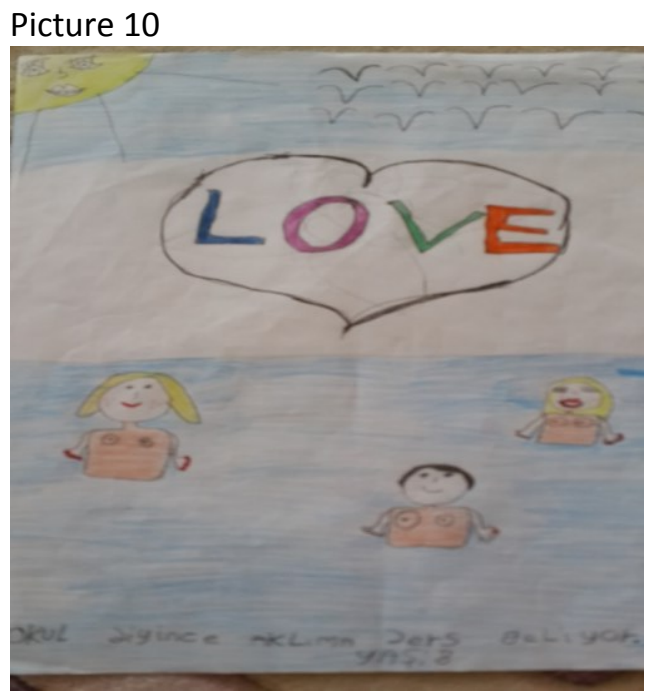

When we look at the drawings of school, 19 students drew the Turkish flag into the picture (See picture 11). Additional to the flag, some of the students, 14 of them; drew a sun and a tree with fruit on it (See picture 12).

Picture 11

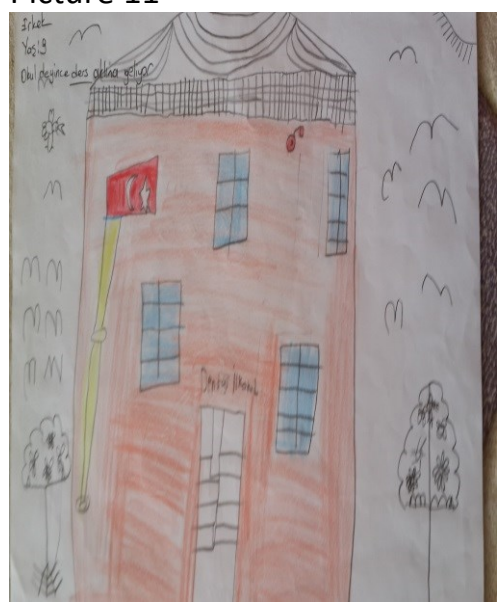

Picture 12

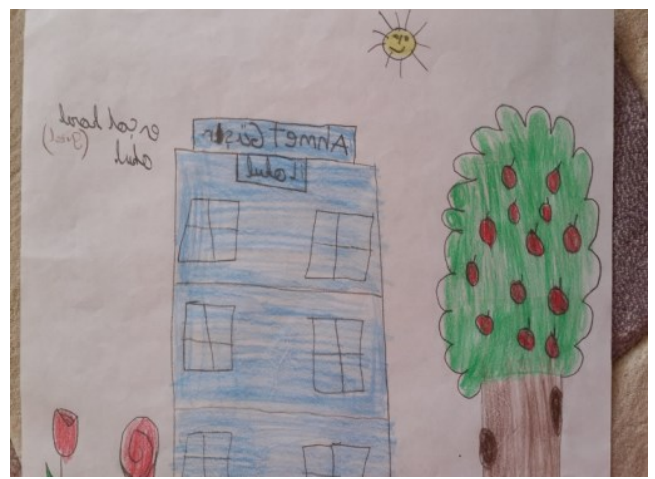

\section{CONCLUSION AND DISCUSSION}

After looking at the drawings of 25 refugee children about the image of a teacher and a school, we should examine what these drawings are tried to tell us. It is a complex process to analyze the pictures. As Yavuzer (1997) stated that "drawing could be regarded as an indicator of mental development and as a way of expressing his or her complex inner world which the child tries to organize on his or her own" (p. 11). Also, children represent their relationship 
with teachers in their drawings naturally. Having children draw pictures is the most appropriate method to get children's feelings in depth. Children reflect their feelings, thoughts, and manners to drawings (Clarke and Ungerer, 2007; Fury, Carlson and Sroufe, 1997).

As it was presented in the findings section, the discussion part will also be separated into two parts; the image of teacher and secondly, the image of school.

\section{Teacher Image}

According to the refugee students' thinking, teachers are a positive influence. Most of the students said that they love their teachers. And they think about teaching, learning and love when they imagine a teacher. Beside their words, drawings also show us they love their teachers. There are many clues for this conclusion. First of all, all drawings are bright and colorful which shows us that these students are in good spirits when they think about a teacher. Also, most of them used hearts and flowers in their drawings. Hearts show us they love their teachers and flowers also show us they have good feelings toward their teachers.

\section{School Image}

Refugee students also think about teaching, learning and lessons when they imagine a school. This shows us that refugee students learn new knowledge in Turkish schools even though some of them are unable to write in Turkish. As stated in the findings section, one of the students said that when s/he thinks about school, traffic rules come into his/her mind. According to this, we can say that for this student there are many rules in school. Besides what refugee students said about school, drawings also show some additional information about students' thinking. Nineteen refugee students drew the Turkish flag into their drawings. Flags in pictures shows us belonging. This means refugee students have a sense of belonging to Turkey and Turkish schools. They don't feel like strangers in schools. Also, fourteen students drew a sun and a tree with fruits on it. The sun means happiness and warmth in picture analyses. Thus, refugee students feel happy in Turkish schools and also feel warmth toward their teachers, school administrators and friends in the school. Trees with fruit means liveliness and action which means these students have a lively or stimulating environment in their schools. They also feel active themselves. Thus, this shows that refugee students don't feel they are alienated from the school environment, but see themselves as active participants.

In conclusion, the words and drawings from refugee children living in Turkey demonstrate that they feel positive about their teachers and schools, and in some cases, love their teachers and schools. They are actively participating, learning and feeling happy to be in Turkish schools. This study reveals encouraging sentiments, resiliency and adaptation from refugee children who 
may have experienced negative or traumatic events related to the war and conflict in Syria.

As with all studies, this study has some limitations. This study could be done with more refugee students to obtain more detailed data. Thus, future studies researchers could do this study with more students from different schools to get diverse data. Additionally, since some of the refugee students don't know Turkish and counselors don't know Arabic language skills, some of the data could be misunderstood. For future studies, interpreters could be included into the study. Also, future studies could be done on comparison of drawings of Turkish students and refugee students to see if any differences exist for images of teacher and school.

\section{References}

Ahi, B., Cingi, M. A., and Kıldan, A. O. (2016). 48-60 Aylık çocukların öğretmen kavramına yönelik algılarının çizimler aracılığıyla incelenmesi. Elementary Education Online, 15(1), 77-90.

Akbulut, M.G. and Saban, A. (2012). An investigation of primary school students' perceptions of violence revealed through their drawings. Turkish Journal of Education, 1(1), 21-37.

Arslan Cansever, B. (2017). The Children's Perceptions of the Teacher: An Analysis of the Drawings Created by the Children. Inönü University Journal of the Faculty of Education, I (18), 281-291. DOI: 10.17679/inuefd.306625

Artut, K. (2002). Sanat Eğitimi Kuramları ve Yöntemleri. (2. Baskı). Ankara: Anı Yayıncilık.

Artut, K. (2007). Okul Öncesinde Resim Eğitimi (2.Baskı). Ankara: Anı Yayıncılık.

Aslan, K., Aslan, N., and Arslan-Cansever, B. (2012). Eğitim bilimine giriş. Ankara: Pegem Akademi.

Atasu, T. R. (2012). Turkiye'de gocmen cocuklarin profili, sosyal politika ve sosyal hizmet onerileri hizli değerlendirme arastirmasi. Uluslararasi Goc Orgutu (International Organization of Migration), Isvicre (Sweden).

Aykaç, N. (2012). İlköğretim öğrencilerinin resimlerinde öğretmen ve öğrenme süreci algısı. Eğitim ve Bilim, 37(164), 228-315.

Barman, C. R. (1997). Students' views of scientists and science: results from a national study. Science and Children; 35(1), 18.

Barone, T. and Eisner, E. W. (2012). Arts based research, Thousand Oaks, CA, Sage. Barnes, E. A. (1893). A Study of children's drawings. Pedagogical Seminary,(3), 451.Barone, T., and Eisner, E. W. (2012). Arts based research. Thousand Oaks, CA: Routledge.

Can Yasar, M. and Aral, N. (2009). Sanat Ürünü Olarak Çocuk Resimleri. Çağdaş Eğitim Dergisi. 34, (365), 24-31.

Çam Aktaş, B. (2010). Investigating primary school students' perceptions regarding 'teacher' through their drawings. The International Journal of Learning, 17(8), 409-425. 
Cherney, I. D., Seiwert, C. S., Dickey, T. M., and Flichtbeil, J. D. (2006). Children's drawings: a mirror to their minds. Educational Psychology, 26(1), 127-142.

Clarke, L., Ungerer, J., Chahoud, K., Johnson, S., and Steifel, I. (2002). Attention deficit disorder is associated with attachment insecurity. Clinical Child Psychology and Psychiatry, 7, 179-198.

Dogutas, A. (2018). Teachers' Perceptions of Refugee Students in Turkish Schools, Multicultural Learning and Teaching, 4 (8), 1-8.

Dotson, M. L. (2007). Educational criticism, a form of arts-based educational research for studying teachers. Journal of Ethnographic and Qualitative Research, 1, 11-20.

Eisner, E. W. (2002). From episteme to phronesis to artistry in the study and improvement of teaching. Teaching and Teacher Education, 18 (4), 375-385.

Fury, G., Carlson, E. A. and Sroufe, L. A. (1997). Children's representations of attachment relationships in family drawings. Child Development, 68, 11541164.

Greenwood, J. (2012). Arts-based research: Weaving magic and meaning. International Journal of Education and the Arts, 13 (Interlude 1). Retrieved 2014 from http://www.ijea.org/v13i1/

Gültekin, Ç., Tosun, Ö., Turgut, Ş., Örenler, Ş., Şengül, K. and Top, G. (2010). Promoting an inclusive, mage of scientists among students: Towards research evidence-based practice. International Journal of Science and Mathematics Education National Science Council, Online. Taiwa.

Harrison, L.J., Clarke, L. and Ungerer, J. A. (2007) Children's drawings provide a new perspective on teacher-child relationship quality and school adjustment. Early Childhood Research Quarterly, 22, 55-71

Huss, E. and Cwikel, J. (2005). Researching Creations: Applying Arts-Based Research to Bedouin Women's Drawings. International Journal of Qualitative Methods, 4(4), 1-16.

Kaplan, N. and Main, M. (1985). Internal representations of attachment at six years as indicated by family drawings and verbal responses to imagined separations. In M. Main (Chair), Attachment: A Move to the Level of Rrepresentation. Symposium Conducted at the Meeting of the Society for Research in Child Development, Toronto, Canada.

Karadağ, Ç. (2004). Görme kültürü (Görüntüler evreni). Ankara: Doruk Yayınları.

Kartal, B., and Basci, E. (2014). Turkiye'ye yonelik multeci ve siginmaci hareketleri, CBU Sosyal Bilimler Dergisi, 12(2), 275-299. http://dx.doi.org/10.18026/cbusos.42910

Leitch, R. (2008). Creatively researching children's narratives through images and drawings. In P. Thomson (Ed.), Doing visual research with children and young people, (pp. 37-59). New York: Routledge.

McNiff, S. (1998). Art-based research. London: Jessica Kingsley Publisher.

McRobbie, A. (1999). Postmodernizm ve popüler kültür (çev. A. Özdek). İstanbul: Sarmal Yayınevi.

Milli Egitim Bakanligi 2010 MEB Yabanci Uyruklu Ogrenciler Genelgesi. Retrieved from 
http://ogm.meb.gov.tr/belgeler/genelge_2010_48.pdf at 10.03.2015

Mirzoeff, N. (1998). What is the visual culture? In N. Mirzoeff (Ed.). Visaul culture reader (pp. 3-14). London and New York: Routledge.

Mitchell, W. J. T. (1995). What is visual culture? In I. Lavin (Ed.), Meaning in the visual arts: Views from the outside (pp. 207-217). Princeton: Institute for Advanced Study.

Mullen, C. (2003). A self-fashioned gallery of aesthetic practice. Qualitative Inquiry, 9(2), 165-182.

Oğuz-Ünver, A. (2010). Perceptions of scientists: a comparative study of fifth graders and fourth year student teachers. Necatibey Eğitim Fakültesi Elektronik Fen ve Matematik Eğitimi Dergisi, 4(1), 11-28.

Pentassuglia, M. (2017). The Art(ist) is present": Arts-based research perspective in educational research, Cogent Education, 4: 1301011, available at https://doi.org/10.1080/2331186X.2017.1301011

Pianta, R. C., Longmaid, K., and Ferguson, K. E. (1999). Attachment-based classifications of children's family drawings: Psychometric properties and relations with children's adjustment in kindergarten. Journal of Clinical Psychology, 28, 244-55.

Rogoff, I. (1998). Studying visual culture. In N. Mirzoeff (Ed.), Visaulculture reader (pp.14-26). London and New York: Routledge.

Sadık, F., Çakan, H., and Artut, K. (2011). Çocuk resimlerine yansıyan çevre sorunlarının sosyo-ekonomik farklılıklara göre analizi. Ilköğretim Online, 10(3), 1066-1080. Retrieved from: http://ilkogretim-online.org.tr

Selwyn, N., Boraschi, D. and Özkula, S.M. (2009). Drawing digital pictures: an investigation of primary pupils' representations of Ict and schools. British Educational Research Journal. 35, (6), 909-928.

Turkcan, B. (2013). Semiotic Approach to the Analysis of Children's Drawings, Educational Sciences: Theory and Practice, 13(1), 600-607.

Türkkan (Türkcan), B. (2008). Ilköğretim görsel sanatlar dersi bağlamında görsel kültür çalışmaları: bir eylem araştırması. Yayımlanmamış doktora tezi, Anadolu Üniversitesi, Eğitim Bilimleri Enstitüsü, Eskişehir.

Yaşar. C. M. and Aral, N. (2009). Sanat Ürünü Olarak Çocuk Resimleri. Çağdaş Eğitim Dergisi,34 (365), 24-31.

Yavuzer, H. (2009). Resimleriyle Çocuk. (3. Baskı). Ankara: Remzi Kitabevi.

Yıldırım, A. and Şimşek, H. (2005). Sosyal Bilimlerde Nitel Araştırma Yöntemleri. Ankara: Seçkin Yayınları. 